Linguista: Jurnal Ilmiah Bahasa, Sastra, dan Pembelajarannya

Vol.3, No.1, Juni 2019, hal 31 - 40

ISSN (print): 2579-8944; ISSN (online): 2579-9037

Avaliable online at: http://e-journal.unipma.ac.id/index.php/linguista

\title{
The Correlation between Grammar and Writing Achievement of EFL Sophomore Students at STKIP PGRI Pasuruan, Indonesia
}

\author{
Lestari Setyowati, Dita Dwi Hardiastikna \\ STKIP PGRI Pasuruan, Jalan Ki Hajar Dewantara 27-29, Kota Pasuruan, Indonesia \\ e-mail: Lestari.setyowati@yahoo.co.id; ditadiastikna11@gmail.com
}

\begin{abstract}
The purpose of this study is to know whether there is a significant correlation between students' grammar mastery and their ability in writing. This research was conducted using quantitative method by using correlational research design. The target population of this research was all fourth semester students of English Education Study Program at Teachers Training and Education (STKIP) PGRI Pasuruan in academic year 2017/2018. The researcher used test and scoring guide as the instruments of this study. In collecting the data, the researcher conducted the writing test and the grammar test. The finding shows that there is no correlation between students' writing ability and their grammar mastery for the fourth semester students of English Education Study Program at STKIP PGRI Pasuruan in academic year 2017/2018. The null hypothesis is not rejected because the significant value is $0.876 \geq 0.05$.
\end{abstract}

Keywords: Corellation; Grammar; Writing

\section{Introduction}

In this modern era, it is very important to master writing skill. That writing is important is undeniable for several reasons. First of all, in general, writing enable people to express themselves and be recognized by somebody else. Second, possessing good writing skill enables someone to get a promising career in his/her future (McKay, 2013). What makes writing important is that most jobs required good writing skills. Fourth, effective writing skills can be the ticket to success and advancement in the workplace. In short, writing skill helps people to get more doors opened for both employment and promotion (UC Berkeley Career Center [UCBCC], 2005) as well as for academic purposes (Fauziati, 2005:147).

Wilson (2011:206) says that for students to do well in their education, learning to write well is very important. However, writing in the native language is quite a difficult skill to master, let alone in the foreign language like English. Septiani (2014) states that no matter how good the students in English, they still need to learn how to transfer their knowledge of grammatical concept from spoken to written language. For the students, writing is a good way to reinforce what they have learned and to enrich and use the vocabulary in written form (Aziz, 2011:371). Communicating the thoughts on to paper and to share them with the readers is called a writing activity (Lewin, 2003:121). When writing is seen as a means of communication, effective communication becomes crucial. Having ideas only is not enough for the writers. The writer needs to arrange the ideas in such a way that they will make sense for the reader. This process of arranging ideas requires the mastery of grammar. Grammar is the rules of how words are combined, arranged, or changed to show certain kinds of meaning (Swan, 2005:19). Dykes (2007:5) 
says that grammar is a language which aims at to talk about language. Thus, as stated by Harmer (2004:31), the use of accurate language should become the focus for the students.

Grammar deals with the form of sentences and smaller units such as clauses, phrases, and words (Huddleston \& Pullum, 2010:1). By learning grammar students can express meanings in the form of phrases, clauses and sentences (Doff, 2000). Willis (2003) identifies three different kinds of grammar. First, grammar of structure that describes the way in which language items link together to form larger units, such as the noun phrase; it is governed by rules and its learning is supported by instruction. Second, grammar of orientation that includes those features that allow the speaker to relate the elements of a sentence, such as verb tense and third, pattern grammar that describes patterns associated with words. Purpura (2004) points out that grammar plays a central role in language teaching, as it influences the success of foreign language learning. It means grammar seems to be influenced all the English skills. In addition, Morenberg (2009) states if the students have good mastery of grammar, they can manage words to become a fully understood sentences.

Previous studies show different findings considering the relationship between grammar and writing. First, Syopiana (2011) conducted a study on the correlation between students' grammar mastery and their ability in writing narrative paragraph. The researcher took the sample by using proportional random sampling technique. There were 32 samples out of 223 populations. In collecting the data, the researcher used test for both variables. The result showed that the score of Pearson product moment $(r)$ is 0.650 and the researcher compared to r-table 5\% and $1 \%$, (df $=30) ; 0.349<(0.650)>$ 0.449 . It means that there is a significant correlation between students' grammar (parallel structure) mastery and their ability in writing narrative paragraph at the second year of SMAN 1 Kuantan Hilir. The second study was conducted by Adhiyatma, Jamiluddin \& Nadrun (2015). They conducted a correlational research on similar topics for science students in SMA Negeri 1 Pasangkayu by using cluster sampling technique. With 40 students as the sample, the result shows that there is a significant correlation between students' grammar mastery and writing ability. Next, Fitria (2016) investigates a correlation between students' simple present tense mastery and their ability in writing descriptive text at first semester of the eighth grade of SMPN 1 Karya Penggawa Pesisir Barat in 2016/2017 academic year. There were 30 samples out of 121 populations. The researcher used cluster random sampling to take the sample and used objective test consisted of 40 items test to test the grammar and writing descriptive text to collect the data. The result showed that there is a positive correlation between students' simple present tense mastery and their ability in writing descriptive text $(\alpha=0.001<0.05)$. The third research was conducted by Puspitasari (2017) on the correlation between students' grammar mastery and their achievement in writing descriptive text. The participants of the study were the first grad of AK-4 at SMKN 1 Bandung. The number of sample were 37 students from 190 populations. The researcher used purposive sampling to take the sample. The result of the research showed that there is positive correlation, the data indicates that the sig (2-tailed) value 0.000 is lower than level of significant. It means that there is significant correlation between students' grammar mastery and their achievement in writing descriptive text at first grades of a state vocational high school in Bandung. And fourthly, Praseno (2017) found a significant correlation between the 1st 
year students' grammar mastery and their writing ability. The subjects of the study were the 1st year students of a state senior high school in Malang. By using, cluster random sampling, the researcher took 56 participants from the 1st year students of SMAN 4 Malang. The result shows that there is a positive correlation between grammar and writing.

However, not all correlational studies between grammar and writing show similar direction. One study conducted by Septiani (2014) investigating grammar mastery and writing ability in university level, shows that there is no correlation between grammar and writing. The researcher used purposive sampling to take the sample. There were 30 students as the sample. In collecting the data, the researcher used the documentation of students' writing scores and grammar test. The result of the research showed that there is no significant correlation between grammar and writing ability. The data showed that the most of the students got the minimum score of grammar but they did not get bad score in writing or they got good score in writing. A newer study was conducted by Febriati (2017) who investigates the relationship between grammar and writing for 40 students of English Language Education Program (ELEP) Faculty of Cultural Studies, Universitas Brawijaya. The result of the study shows that the correlation between grammar and writing cannot be found as the null hypothesis cannot be rejected.

Having discussed the previous research, more studies need to be conducted to reveal whether a correlation does exist between grammar and writing, in EFL context, especially in university level. To fill the gap, this research is intended to investigate the correlation between grammar mastery and writing ability of fourth semester students in English Education Study Program at STKIP PGRI Pasuruan.

\section{Method}

This research used quantitative approach by focusing on correlation design. Muijs (2004:1) says that quantitative research explains the phenomena by collecting numerical data that are analyzed by using mathematical methods. Best \& Khan (2006:378) and Lodico et al (2006:14) define correlation as the relationship between two or more paired variables. There are two variables in this research. They were grammar mastery as $X$ variable and writing ability as $Y$ variable.

The target population of this research was the whole fourth semester students (49 students) of English Education Study Program at STKIP PGRI Pasuruan in academic year 2017/2018. There are 25 students from A class and 24 students from B class. Because the total number of the population was less than 100, the researchers decided to take all the target population of the fourth semester students of English Education Study Program at STKIP PGRI Pasuruan.

The instruments used in the study were tests (grammar test and writing test) and scoring guide for writing. For writing test, the researcher used an essay writing test as the test instrument to collect the data. Before conducting the writing test, the researcher did some stages for test development, such as developing, validating, trying out, and assembling the final format of the test. The direct writing test was in the form of an essay with the theme of bullying. The students should choose one topics which they thought was interested to write. The topics were (1) the cause and effect of physical/verbal/cyber bullying; (2) solving the problems of bullying, (3) comparing and contrasting types of 
bullying (physical/verbal/cyber bullying), and (4) comparing traditional bullying and cyber bullying. The students' composition was scored by Jacobs ESL Composition Profile. This profile was developed by Jacobs and colleagues (Jacobs, Zingraf, Wormuth, Hartfiel, \& Hughey, 1981) and rated by two raters. This profile has a 100 -point scale by five different criteria such as; content (30 points); organization (20 points); vocabulary (20 points); language use (25 points); mechanics (5 points).

In grammar test, the researcher collaborated with grammar lecturer to conduct the test. Based on the basic course outlines of grammar course, the course was designed to develop the students' ability in doing the TOEFL test. In conducting the test, the lecturer and the researchers used NST TOEFL Explorer as the test. NST TOEFL Explorer has a complete application equipped with TOEFL exercises and examination sections. So, before the students did the test, they could practice or study in the exercise section beforehand. NST TOEFL Explorer is an application (Computer Based TOEFL) produced by NST Electronic Publishing Co., Ltd. There are 40 items of multiple choice used for the test. The writing test and the grammar test were administered in different days. The data collected from the tests were analyzed by using IBM SPSS 23.

\section{Finding and Discussion}

\section{The result of the writing scores reliability}

The data from the writing test was rated by two raters. Since writing test was considered subjective type test, the researchers decided to find out whether the scores were reliable. The scores from rater one and rater two were analyzed by using Pearson product moment correlation to know the reliability coefficient. The reliability coefficient is 0,562 . It means, the consistency between the first and second rater was moderate in reliability.

Table 1. Correlations between raters

\begin{tabular}{llrr}
\hline & & RATER_ONE & RATER_TWO \\
\hline RATER_ONE & Pearson Correlation & 1 & $.562^{* *}$ \\
\cline { 2 - 4 } & Sig. (2-tailed) & 49 & .000 \\
\cline { 2 - 4 } & $\mathrm{N}$ & $.562^{* *}$ & 49 \\
\hline \multirow{2}{*}{ RATER_TWO } & Pearson Correlation & .000 & 1 \\
\cline { 2 - 4 } & Sig. (2-tailed) & 49 & 49 \\
\cline { 2 - 4 } & $\mathrm{N}$ & \\
${ }^{* *}$. Correlation is significant at the 0.01 level (2-tailed) &
\end{tabular}

Table 1 shows that the scores between rater one and rater two have positive association. The writing scores from two raters are reliable and it can be seen from the coefficient correlation above

\section{Description of students' ability}

Knowing the students' ability in both variables are needed. The researcher presents the frequency distribution for both variables to know the description of students' ability based on their scores. 

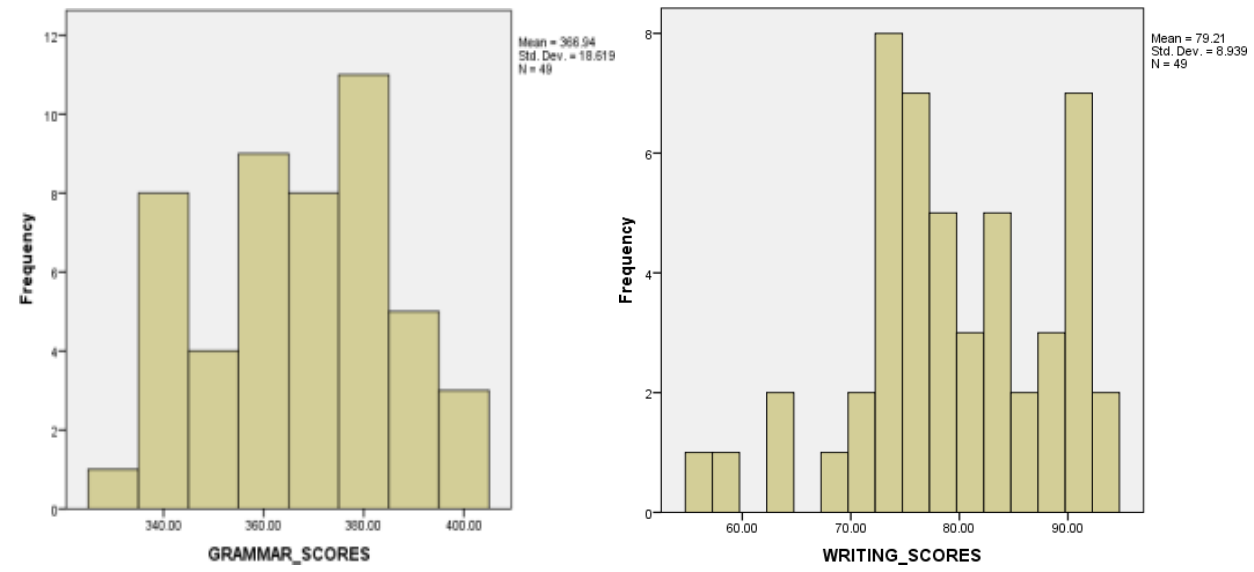

Figure 1. The Frequency Distribution of Grammar Scores and writing scores

Figure 1., shows how the scores are distributed. In grammar test, the data shows that there are three students got the highest score but only one student got the lowest score. The mean of the grammar scores is 366.94 . Meanwhile, the data from writing scores shows that the scores tend to go to the positive direction, one student got the lowest score, and two students got the highest scores. The mean of writing scores is 79.21.

\section{The Fulfillment of Statistical Assumption}

The statistical assumption should be checked before analyzing the data by using Pearson correlation product moment. There are four assumptions that should be fulfilled. Assumption one

The criteria in assumption one is the two variables which would be measured should at the interval or ratio level. Interval variable also known as continuous variable where the variable can be measured in numerical data. Based on Latief (2016:11) the example of continuous variables are intelligence, self- esteem, academic achievement and language skills. In this research, the variables are grammar and writing which means included into academic achievement where the result can be measured in numerical data. In conclusion the variables of this research are already at the interval level.

\section{Assumption two}

The criteria in assumption two is a linear relationship for two variables. For investigating the linearity, the researcher checked the data by using scatter plot.
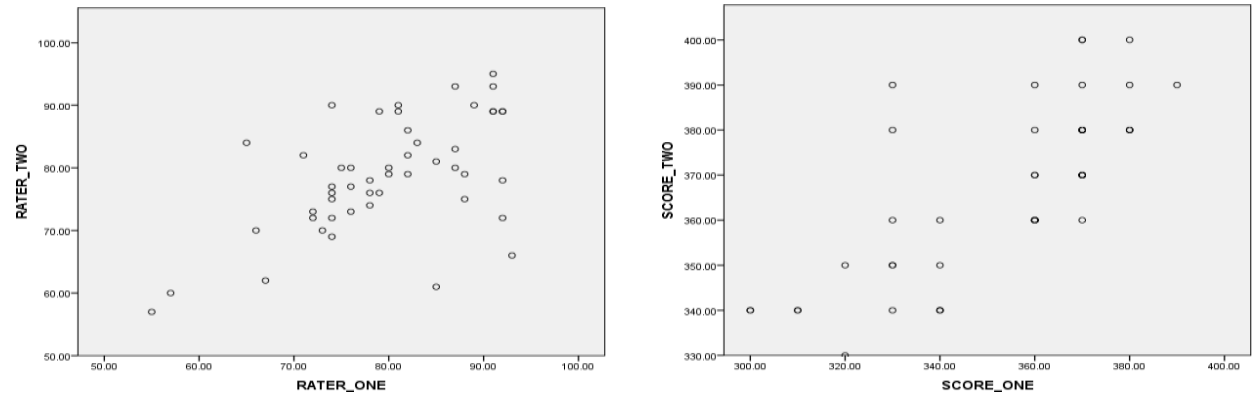

Figure 2. Scatter Diagram of Writing Scores and grammar scores

Figure 2 shows the linearity assumption of the two variables. The first scatter plot follows the straight line, so it indicated that writing variable has a linear relationship. 
On other hand, the second scatter plot of grammar variable does not show linear relationship.

\section{Assumption three}

In assumption three, the data should be no significant outliers. The researcher checked the outliers for both variables as bellow:
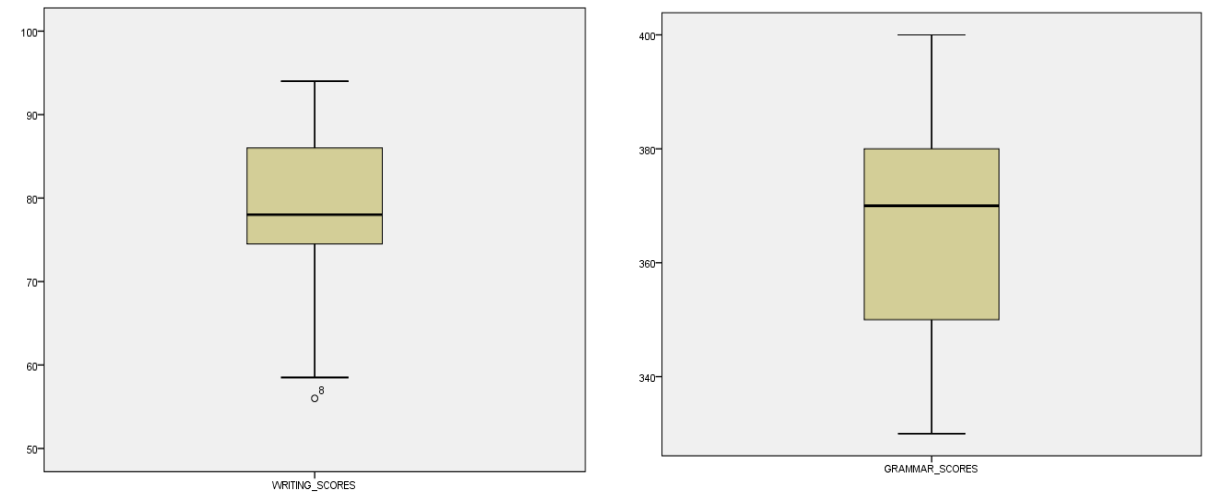

Figure 3. Outlier in Writing and grammar scores

Figure 3 shows that there is one outlier in writing scores. But no significant outlier in grammar scores in the second box plot. Since there should be no outliers in the data, the significant outlier in the writing scores was deleted to be able to use Pearson product moment correlation.

\section{Assumption four}

In the last assumption, the criteria of the two variables should be approximately normally distributed. To test for normality, the researcher used the Shapiro-Wilk test of normality. To fulfill the criteria of assumption four, the researcher showed the result of normality test for both variables as follow.

Table 2. Test of Normality

\begin{tabular}{lllllll}
\hline & \multicolumn{3}{l}{ Kolmogorov-Smirnov ${ }^{\mathrm{a}}$} & \multicolumn{3}{l}{ Shapiro-Wilk } \\
\cline { 2 - 6 } & Statistic & $\mathrm{df}$ & Sig. & Statistic Df & Sig. \\
\hline WRITING_SCORES & .104 & 48 & $.200^{*}$ & .967 & 48 & .188 \\
\hline GRAMMAR_SCORES & .150 & 48 & .009 & .943 & 48 & .021 \\
\hline
\end{tabular}

*. This is a lower bound of the true significance.

a. Lilliefors Significance Correction

Table 2 shows the results of two well-known tests of normality; KolmogorovSmirnov test and Shapiro-Wilk. In this research, the researcher focused on Shapiro- Wilk test because the sample is less than 50 . The result of Shapiro-Wilk test shows that the writing scores are distributed normally, whereas the data from the grammar scores shows differently. On other word, the data of grammar variable significantly deviates from a normal distributed data.

Data analysis

Since not all the assumption could be fulfilled, the data in this research was computed by using nonparametric correlation or Spearman's rho because the grammar scores did not have normality distribution, or the normality was violated, and it had no linear relationship. 
Table 3. Spearman's rho Correlations Nonparametric Correlations

\begin{tabular}{|c|c|c|c|c|}
\hline & & & $\begin{array}{l}\text { WRITING } \\
\text { SCORE }\end{array}$ & $\begin{array}{l}\text { GRAMMAR } \\
\text { SCORE }\end{array}$ \\
\hline \multirow[t]{6}{*}{ Spearman's rho } & WRITING_SCORE & $\begin{array}{l}\text { Correlation } \\
\text { Coefficient }\end{array}$ & 1.000 & -.023 \\
\hline & & Sig. (2-tailed) & . & .876 \\
\hline & & $\mathrm{N}$ & 48 & 48 \\
\hline & $\begin{array}{l}\text { GRAMMAR_SCOR } \\
\mathrm{E}\end{array}$ & $\begin{array}{l}\text { Correlatio } \\
\mathrm{n} \\
\text { Coefficient }\end{array}$ & -.023 & 1.000 \\
\hline & & Sig. (2-tailed) & .876 &. \\
\hline & & $\mathrm{N}$ & 48 & 48 \\
\hline
\end{tabular}

Based on the result of Spearman's rho correlations computation, the significant value is obtained is 0.876 . This means that, the research fails to reject the null hypotheses because the significant value is higher than the alpha value $(0.876 \geq 0.05)$. On other word, there is no correlation between students' writing ability and their grammar mastery for the fourth semester students of English Education Study Program at STKIP PGRI Pasuruan in academic year 2017/2018.

Research has shown that there is a positive relationship between grammar and writing (Syopiana, 2011; Fitria, 2016; Puspitasari 2017). This means that one who has good mastery of grammar tends to have good writing ability. However, in this present study, the result shows that there is no significant correlation between grammatical ability and writing. Although the result seems to suggest that there is no correlation between grammar and writing, the discussion of this finding should be done carefully. There are several possible explanations that may lead to the failure to reject the null hypothesis. Those possible causes probably are (1) the characteristics of the course in university level, (2) the validity of the grammar test instrument; (3) the ability of the writing scorer, and (4) the nature of EFL writers.

Firstly, the result of this study rejects the previous studies in EFL context conducted by Syopiana (2011), Adhiyatma, Jamiluddin \& Nadrun (2015), Fitria, (2016), and Puspitasari (2017) which were done in the middle school where the teaching of grammar is integrated into the teaching of writing. In contrast, the result of this study corresponds to the studies conducted by Septiani (2014) and Febriati (2017) who conducted correlational research between grammar and writing in University level. It becomes understandable why the correlation between grammar and writing in the previous studies is proven to be significant. It is all because in the middle schools in Indonesia, when the students are taught particular writing genre, they would learn the generic structure and language feature used in that genre. Whereas, in the university level, the teaching of grammar and the teaching of writing are mostly done in isolation. In university level, grammar and writing are two different courses which often teach different topics which are often not taught integratedly. The result of this study might be different if the students under study were taught grammar used for their essay, just like what the students in the middle school do.

The second possible cause is the grammar test instrument used in this study which needs to be rechecked for its validity. TOEFL test is known to be a valid test. However, in this study, the researcher used NST TOEFL explorer which is basically an application for learning or practicing TOEFL test (Mabaroh \& Pusparini, 2018). To have more valid and reliable test, this instrument needs to be tried out. The third possible 
cause is the writing raters. In this research, the writing scoring rubric used was Jacobs ESL Composition profile. This rubric has five writing elements to score the students' essay, namely content, organization, vocabulary, language, and mechanics. The range of the score in the rubric ranges from 0 to 100. Thus, Jacobs ESL composition profile is considered a sensitive rubric as compared to primary trait scoring guide (Setyowati, Latief, \& Widiati, 2016) and a well-known rubric in ESL writing fields (Brooks, 2012). To gain high inter-rater reliability, there should be some training for the scorers/raters (Wang, 2009). Training the raters to score similar composition by using similar rubric could maximize the accuracy of writing assesment and minimize the differences as a result of different background. Thus, two raters involved in this study basically should be given more training how to score the students' writing before the actual rating. The training mainly gave emphasis on raters' understanding of the intended rating criteria.

And the fourth explanation is lays in the nature of EFL writer itself. First language (L1) and Second language/foreign language (L2/EFL) writing are different in its nature. Raimes (1985) reports her finding that $L 2$ writers, especially the unskilled ones, unlike the L1 writers, give more concerns with generating ideas than language. Similarly, Silva (1997) also states that ESL writers prefer not to plan and not to review their writing unlike the L1 writers. ESL/EFL learners struggle more with the vocabulary to present ideas which cause them difficulty in writing. When writing is viewed as the communication between the writer and the reader, grammar will not be the main factor that determines a good writing. When the communication takes place, the most important thing is how the idea is transmitted and understood by the readers, especially in the context of L1 and L2 writing (Huang, 2011). Silva (1997) believes that aside from linguistic form, ideas and rhetorical control are the crucial elements in writing. In this research, the students who have high scores in writing, do not necessarily have good scores in grammar, and vice versa. The result of this research corresponds to Davis \& Mahoney (2005) research which says that the use of correct grammar does not necessarily result in overall good writing ability. They further state that detecting errors and teaching correct grammar for writing give little effect to students' ability in eliminating their own errors in their own essays and counterproductive for writing. The result of this study also confirm a correlational study conducted by Septiani (2014) in which she states that the students who perform poor in grammar do not necessarily perform poor in their writing performance.

\section{Conclusion}

In this present study, no correlation was found between students' writing ability and their grammar mastery for the fourth semester students of English Education Study Program at STKIP PGRI Pasuruan in academic year 2017/2018 as the significant value is $0.876 \geq 0.05$. In this research, it was found that the students who are good at grammar do not necessarily well at writing, and vice versa. However, further study needs to be done to confirm this finding.

Some suggestions are addressed for future researchers if this study should be replicated. Firstly, the grammar instrument used in the study should be validated and adequately reliable for the purpose of the research, not for the purpose of the teaching of particular subject. Thus the grammar test should follow the steps of research and development procedure, namely planning, developing, validating, trying out, and revising the final product. Should the future researcher used TOEFL test available on the internet, 
it has to be tried out to find out its validity and reliability. Secondly, future researchers should have some specific time to train the raters to score the students' composition. Since writing has high subjectivity, the raters need to have adequate knowledge for each element of writing which should be scored and how to score it. The used of particular writing rubric need some adjustment, skill and training to be able to use the rubric optimally. In conclusion, more studies need to be conducted to find out to reveal the truth whether grammar and writing in university level are truly correlated.

\section{References}

Adhiyatma, B., Jamiluddin, J., \& Nadrun, N. 2015. The Correlation Between Students' Mastery of Grammar and Writing Ability of the Tenth Grade. e-Journal of English Language Teaching Society (ELTS). 3 (2): 1-12

Aziz, S. S. (2011). Analysis of Errors in Paragraph Writing in English by Second Year Geography and History Students at University of Baghdad. Journal of College of Education for Women, 22 (2): 371-387

Best, J.W. \& Kahn, J. (2006). Research in Education. New Delhi: Prentice Hall of India Pvt. Ltd.

Davis, W \& Mahoney, K. (2005). The Effects of Grammar Testing on the Writing Quality and Reduction of Errors in College Freshmen's Essays.

Doff, A. (2000). Teach English: A Training Course for Teachers (14th Ed). Cambridge: Cambridge University Press.

Dykes, B. (2007). Grammar for Everyone. Victoria. ACER Press.

Fauziati, E. (2005). Teaching of English as A Foreign Language. Surakarta: Muhammadiyah University Press.

Febrianti, M. (2017). The Correlation Between Grammar And Writing Achievement (A Correlation Study At The 2nd Semester Of English Language Education Program (Elep) Students Of Universitas Brawijaya In Academic Year 2016/2017). Sarjana thesis, Universitas Brawijaya.

Fitria, E. (2016). The Correlation between Students' Simple Present Tense Mastery and their Ability in Writing Descriptive Text. Bandar Lampung: State Institute of Islamic Studies Raden Intan Lampung.

Harmer, J. (2004). How to Teach Writing. England: Longman.

Huang, Y.H. (2011). Does EFL Students' Grammatical Ability Account For Writing Ability? A Case Study. Chia-Nan Annual Bulletin. 37: 500-511

Huddleston, R.D \& Pullum, G. K. (2010). A Students's Introduction to English Grammar. New York: Cambridge University Press.

Jacobs, H. L., Zinkgraf, S. A., Wormuth, D. R., Hartfiel, V. F., \&Hughey, J. B. (1981). Testing ESL composition; A practical Approach. Newbury House, Rowley, MA.

Latief, M. A. (2016). Research Methods on Language Learning an Introduction 2nd Edition. Malang: Universitas Negeri Malang.

Lewin, L. (2003). Paving the Way in Reading and Writing (Strategies and Activities to Support Struggling Students in Grade 6- 12). San Francisco. Jossey Bass.

Lodico, M. G., Spaulding, D. T., Voegtle, K. H. (2006). Methods in Educational Research from Theory to Practice. San Fransisco: Jossey-Bas. 
Mabaroh, B., \& Pusparini, D.A. (2018). Konsiderasi Untuk Menerapkan Student Grouping Dalam Pembelajaran Tata Bahasa TOEFL Dengan Menggunakan Aplikasi NST TOEFL Explorer. Jurnal Bahasa Lingua Scientia, 10 (2): 247-264. DOI: dx.doi.org/10.21274/ls.2018. 10.2.247-264

Morenberg, M. (2009). Doing Grammar.New York: Oxford University Press.

Muijs, D. (2004). Doing Quantitative Research in Education. India: Sage Publications.

Praseno, M D. (2017) Correlation between Grammar Mastery and Students' Writing Ability among the 1st Year Students of SMAN 4 Malang. Sarjana thesis, Universitas Brawijaya.

Purpura, J.E. (2004). Assessing Grammar. Cambridge: Cambridge University Press.

Puspitasari, D. (2017). The Correlation Between Student' Grammar Mastery and Their Achievement in Writing Descriptive Text. State Islamic Institute. Tulungagung,

Raimes, A. (1985). What skilled ESL students do as they write: A classroom study of composing. TESOL Quarterly, 19, 229-258.

Septiani, R. (2014). The Correlation between Grammar Mastery and Writing Ability. UIN Syarif Hidayatullah. Jakarta, (Online).

Setyowati, L., Latief, M.A, Widiati, U. (2016). The Implementation of Planning and Its Effect on EFL Students' Writing Performance. Jurnal IImu Pendidikan, 22 (1): 2635.

Silva, T. (1997). Differences in ESL and native-English-speakers writing: The research and its implications. In C. Severino, J.C. Guerra \& J.E. Butler (Eds.), Writing in multicultural settings, 215-219. New York: The Modern Language Association of America.

Swan, M. (2005). Practical English Usage. 3rd Edition. Oxford. Oxford University Press.

Syopiana. (2011). The Correlation between Students' Grammar and their Ability in Writing Narrative Paragraph at the Second Year of SMAN 1 Kuantan Hilir. State Islamic University of Sultan Syarif Kasim Riau. Pekanbaru, (Online) (http://repository.uin- suska.ac.id/270/), accessed on March 15, 2018.

UC Berkeley Career Center. (2005). Writing Matters: Writing Well May Be the Key to Getting a Job or a Promotion. (Online). Retrieved from (https://career.berkeley.edu /article/ 050408b-dm.stm), accessed on 14 March 2013.

Wang, P. (2009). The Inter-rater Reliability in Scoring Composition. English Language Teaching, 2(3):39-43.

Willis, D. (2003). Rules, Patterns and Words: Grammar and Lexis in English Language Teaching. United Kingdom: Cambridge.

Wilson, P. (2011). The Least You Should Know about English, Writing Skills, Form A, Tenth Edition. USA: Wadsworth. 